\title{
Protective antigens against glanders identified by expression library immunization
}

\author{
Gregory C. Whitlock ${ }^{1+\neq}$, Mark D. Robida ${ }^{2 \ddagger}$, Barbara M. Judy ${ }^{3}$, Omar Qazi ${ }^{4}$, Katherine A. Brown ${ }^{4,5}$, \\ Arpaporn Deeraksa ${ }^{3}$, Katherine Taylor ${ }^{3}$, Shane Massey ${ }^{1,3}$, Andrey Loskutov ${ }^{2}$, Alex Y. Borovkov ${ }^{2 \dagger}$, \\ Kevin Brown ${ }^{2}$, Jose A. Cano ${ }^{2 \dagger}$, D. Mitchell Magee ${ }^{2}$, Alfredo G. Torres ${ }^{1,3,6}$, D. Mark Estes ${ }^{1 \dagger}$ and \\ Kathryn F. Sykes ${ }^{2,7 *}$
}

1 Department of Microbiology and Immunology, University of Texas Medical Branch, Galveston, TX, USA

${ }^{2}$ Center for Innovations in Medicine in the Biodesign Institute, Arizona State University, Tempe, AZ, USA

${ }^{3}$ Department of Pathology, University of Texas Medical Branch, Galveston, TX, USA

${ }^{4}$ Institute for Cellular and Molecular Biology, University of Texas, Austin, TX, USA

${ }^{5}$ Department of Chemistry and Biochemistry, University of Texas, Austin, TX, USA

${ }^{6}$ Sealy Center for Vaccine Development, University of Texas Medical Branch, Galveston, TX, USA

7 School of Life Sciences, Arizona State University, Tempe, AZ, USA

\section{Edited by:}

Ivo Steinmetz, University of

Greifswald, Germany

\section{Reviewed by:}

Shu-Lin Liu, Harbin Medical

University, China

Baolin Sun, University of Science and

Technology of China, China

*Correspondence:

Kathryn F. Sykes, Center for Innovations in Medicine, Biodesign

Institute, School of Life Sciences,

Arizona State University, 1001

McAllister Avenue, Tempe, AZ 85287-5901, USA.

e-mail: kathryn.sykes@asu.edu

${ }^{\dagger}$ Present address:

Gregory C. Whitlock, Roche

Diagnostics, Inc., Indianapolis, IA

46250, USA;

Alex Y. Borovkov, Synbuild LLC,

Mesa, AZ 85201, USA;

Jose A. Cano, Universidad Politecnica

del Estado de Morelos, Biotecnologia, Jiutepec, Morelos Mexico, Mexico;

D. Mark Estes, Department of

Infectious Diseases, College

of Veterinary Medicine, Univerity of

Georgia, Athens, GA 30602, USA.

${ }^{\ddagger}$ Gregory C. Whitlock and Mark D.

Robida have contributed equally to

this work.
Burkholderia are highly evolved Gram-negative bacteria that primarily infect solipeds but are transmitted to humans by ingestion and cutaneous or aerosol exposures. Heightened concern over human infections of Burkholderia mallei and the very closely related species B. pseudomallei is due to the pathogens' proven effectiveness as bioweapons, and to the increased potential for natural opportunistic infections in the growing diabetic and immunocompromised populations. These Burkholderia species are nearly impervious to antibiotic treatments and no vaccine exists. In this study, the genome of the highly virulent $B$. mallei ATCC23344 strain was examined by expression library immunization for gene-encoded protective antigens. This protocol for genomic-scale functional screening was customized to accommodate the unusually large complexity of Burkholderia, and yielded 12 new putative vaccine candidates. Five of the candidates were individually tested as protein immunogens and three were found to confer significant partial protection against a lethal pulmonary infection in a murine model of disease. Determinations of peripheral blood cytokine and chemokine profiles following individual protein immunizations show that interleukin-2 (IL-2) and IL-4 are elicited by the three confirmed candidates, but unexpectedly interferon- $\gamma$ and tumor necrosis factor- $\alpha$ are not. We suggest that these pathogen components, discovered using genetic immunization and confirmed in a conventional protein format, will be useful toward the development of a safe and effective glanders vaccine.

Keywords: Burkholderia, B. mallei, glanders vaccine, expression library immunization, functional genomics, genetic immunization, DNA vaccine, subunit vaccine

\section{INTRODUCTION}

Burkholderia mallei remains an endemic pathogen in many parts of the world including Africa, Asia, the Middle East, and South America (Elschner et al., 2011). This Gram-negative, facultative aerobic bacillus primarily infects solipeds, with horses considered the natural reservoir; however, human infections occur zoonotically. The course of disease depends on the route of infection. Direct contact with the skin leads to a localized cutaneous infection called farcy. Contact with nasal or oral mucosal surfaces or inhalation lead to a highly infectious, painful, and incapacitating disease called glanders (Nierman et al., 2004). Acute symptoms include coughing, fever, and the release of infectious nasal discharge. Nodular lesions form in the lungs and ulcers develop in the mucous membranes of the upper respiratory tract. Without aggressive antibiotic treatment disease progresses to septicemia and is nearly $100 \%$ fatal (Waag et al., 2005). Survivors can suffer chronic infections of the muscle liver and spleen for up to 20 years, and remain carriers (Whitlock et al., 2008). Even if quickly diagnosed, antibiotic treatments have shown low efficacy and require long regimens with multiple drugs. Moreover, no vaccine candidate has even progressed to a clinical trial (Kenny et al., 1999; Leelarasamee, 2004; Bondi and Goldberg, 2008). These therapeutic hurdles arise from a number of pathogen characteristics including its ability to reside in the vacuoles of eukaryotic cells. Other immune evading tactics, including high genomic variability (Nierman et al., 2004), have rendered the performance of even live 
vaccines disappointing (Ulrich et al., 2005). In addition to being a naturally occurring disease, glanders has been used as a bioweapon against cavalry in the American Civil War, World War I, and World War II (Nierman et al., 2004). The severe nature of the disease and the lack of treatment options, combined with the potential for microbe aerosolization, have made $B$. malle $i$ a member of the Center for Disease Control and Prevention category B Priority Agent list.

Immune correlates of protection for $B$. mallei are not well developed. Its capacity to replicate inside host cells suggests that cell-mediated responses are likely to be linked to protection. However, vaccine studies with heat-killed (HK) B. mallei strains, either encapsulated or not, elicited mixed $\mathrm{T}$ helper cell type 1 /type 2 responses in mice that were only weakly protective (Amemiya et al., 2002; Whitlock et al., 2008). A live capsule-deficient $B$. mallei mutant was not protective; however, aerosol immunization with a live-attenuated auxotrophic mutant conferred 50\% survival against aerosol challenge, although the mice were unable to clear the infection. This strain was shown to elicit a Th1-skewed antibody response (IgG2a > to IgG1; Ulrich et al., 2005). In a recent study, the type III secretion system protein BopA was shown to improve survival rate, but also failed to provide sterilizing immunity. It generated a strong Th1-skewed antibody response and $\mathrm{T}$ cells that produced $\gamma$-interferon (IFN $\gamma$; Whitlock et al., 2010).

Although not optimal, the protection conferred by the live B. mallei strain and BopA indicate that developing a Burkholderia vaccine is possible. The inherent advantage of a liveattenuated vaccine is that no antigen identification or development is required, and broad antigenic diversity is possible because all components are delivered. Molecular component vaccines are an alternative to the use of live or killed preparations. A component design enables immense control relative to whole-pathogen compositions for improving manufacture, product safety and consistency, and vaccine efficacy; however, antigen discovery is required. Discovery is a considerable challenge for Burkholderia species because of the unusual fluidity and large size of their genomes, the functional and antigenic diversity of isolates, and the exceptional complexities of the immune responses that infection can elicit (Holden et al., 2004; Nierman et al., 2004; U'Ren et al., 2007). These factors suggest that if a component design is pursued, multiple components will need to be discovered to confer robust protection. Toward this purpose, over 1500 complete bacterial genome sequences are currently published (Relman, 2011). However, the characteristics of a pathogen component that make it protective are poorly understood. Furthermore, a substantial portion of the open reading frames (ORFs) in microbial databases remain without known function (Cui et al., 2005), thereby restricting sequence-based analyses as a method of candidate discovery.

In addition to in silico analyses, the large microbial sequence databases can be used for the design and construction of genes and proteins for empirical testing as antigens. New molecular technologies have begun to provide solutions for making production and testing possible on genomic scales. For example, through genetic immunization (Tang et al., 1992) libraries of constructed genes expressing the full coding capacity of a pathogen genome can be delivered into an animal to elicit immune responses to the pathogen proteome in a process termed expression library immunization (ELI; Barry et al., 1995). These libraries are introduced into animals as organized sub-library pools from which individual ORFs are identified for further study based on their ability to stimulate immunity against pathogen challenge. To avoid thousands of time-consuming and bias-ridden cloning steps, we developed linear expression elements (LEEs) that can be rendered genetically active by simply attaching desired expression sequences such as a promoter and terminator (Sykes and Johnston, 1999b). This study demonstrates the utility of a modified ELI method for the discovery of $B$. mallei component vaccine candidates. BALB/C mice were immunized with LEE pools expressing the $B$. mallei ATCC23344 ORF-eome. To address the individual dose diluting effects of the highly mixed ORF pools, a two-dimensional pooling strategy with divergent complexities was applied. In addition, LEEs were gene gun administered using a modified DNA/goldparticle formulation that prevented DNA loss during bombardment. Challenge-protection assays identified 12 ORFs as potential vaccine candidates. Testing of 5 of these 12 candidates individually in a protein subunit format confirmed that three confer significant partial protection against pulmonary challenge and showed that they elicit a CD4-like T cell cytokine response.

\section{MATERIALS AND METHODS B. MALLEI CULTURING AND GENOMIC DNA ISOLATION}

Burkholderia mallei strain ATCC 23344 (China 7) was cultured on Luria-Bertani (LB) agar plates supplemented with $4 \%$ glycerol agar plates for $48 \mathrm{~h}$ at $37^{\circ} \mathrm{C}$. Isolated colonies were sub-cultured to LB broth with $4 \%$ glycerol, and incubated at $37^{\circ} \mathrm{C}$ until exponential growth phase was reached. To obtain $\mathrm{HK}$ inoculums, bacterial suspensions were incubated at $85^{\circ} \mathrm{C}$ for $3 \mathrm{~h}$ and stored at $4^{\circ} \mathrm{C}$ until use. The absence of live B. mallei organisms in the HK preparations was confirmed by plating $10 \%$ of the total inoculums (v/v) and incubating these at $37^{\circ} \mathrm{C}$ for $48 \mathrm{~h}$. All procedures were performed under biosafety level-3 containment.

To isolate genomic DNA, bacilli were cultured at $37^{\circ} \mathrm{C}$ in $\mathrm{LB}$ broth for $18 \mathrm{~h}$ and then pelleted at $3000-5000 \mathrm{~g}$ for $5-10 \mathrm{~min}$ at room temperature. The cells were resuspended in $1 \mathrm{ml}$ of buffer B1 (with RNase A; Qiagen, Valencia, CA, USA) to obtain efficient lysis of the bacteria, then $20 \mu$ l of lysozyme stock solution and $45 \mu \mathrm{l}$ of Proteinase $\mathrm{K}$ solution were added and the samples were incubated at $37^{\circ} \mathrm{C}$ for at least $30 \mathrm{~min}$. Buffer $2(0.35 \mathrm{ml})$ was added and tubes were mixed and incubated at $50^{\circ} \mathrm{C}$ for $30 \mathrm{~min}$ in a heatblock. Lysates were added to a Qiagen Genomic-tip 500/G purification column and genomic DNA was extracted following manufacturer's instructions.

\section{ORF AMPLIFICATION, LEE ASSEMBLY, AND GENETIC ADJUVANT PREPARATION}

The genomic sequence of the two chromosomes of $B$. mallei ATCC23344 were downloaded from GenBank (accession no. CP000010; CP000011). The genome contains a predicted total of 5535 genes (Nierman et al., 2004). In-house software (GeneSplitter) was used to confirm coding sequence annotations and assign a project number to each gene. To design the project's ORF-eome, all genes of $1 \mathrm{~kb}$ or less were generated as full length gene ORFs; genes longer than $1 \mathrm{~kb}$ were generated as a set of $\sim 800$ bp long sub-genes overlapping by approximately $100 \mathrm{bp}$, thereby increasing the number of total ORFs in the library. If no primers could be designed to specifically amplify individual 
members of a gene family, then the whole family was permitted to be amplified with a single oligo pair and this was recorded. The resulting mixed PCR product was designated with a single ORF number, thereby decreasing the total number of numerically defined ORFs relative to the annotation. Using these rules, a total of 6630 unique $B$. mallei ORFs were electronically defined; a corresponding number of ORF specific primer pairs were predicted and obtained containing a $5^{\prime}$ common forward or reverse region in addition to the ORF specific sequences. In a first step PCR, ORFs were amplified by 20 cycles of denaturation at $98^{\circ} \mathrm{C}, 40 \mathrm{~s}$ of annealing at $66^{\circ} \mathrm{C}$, and $2 \mathrm{~min}$ of extension at $72^{\circ} \mathrm{C}$ from $\sim 100$ to $150 \mathrm{ng}$ of $B$. mallei ATCC23344 genomic DNA. The MasterTaq Kit $\left(5^{\prime}\right)$ was used with $1 \times$ Taq buffer with $\mathrm{MgCl}_{2}, 1 \times$ Taq Master PCR Enhancer, 0.5 units of Taq, $200 \mu \mathrm{M}$ dNTPs, and $200 \mathrm{nM}$ of ORF specific primers with a common adapter region (forward primers: GGTATAGGCGGAAGCGGATTG; reverse primers: GTGGGAGGGAGGTTAGGT) in a total volume of $10 \mu \mathrm{l}$. Universal primers were designed for use in a second step PCR with the common adapter region preceded by a region containing deoxyuracil $(\mathrm{dU})$ phosphoramidite bases at intervals of three within a short $5^{\prime}$ stretch of the ORFs (forward primer: AGUAGUA GUAGUAGUGGTATAGGCGGAAGCGGATTG; reverse primer: AUGAUGAUGAUGAUGAUGTGGGAGGGAGGTTAGGT). This reaction was set up as a $90-\mu l$ master mix containing $1 \times$ Taq buffer with $\mathrm{MgCl}_{2}, 1 \times$ Taq Master PCR Enhancer, five units of Taq (Invitrogen), $200 \mu \mathrm{M}$ dNTPs, and $250 \mathrm{nM}$ of the dU-universal primers, which was then added to the $10-\mu l$ first step PCR reaction product. Amplification was conducted with 5 cycles of $30 \mathrm{~s}$ denaturation at $98^{\circ} \mathrm{C}, 40 \mathrm{~s}$ of annealing at $50^{\circ} \mathrm{C}$, and $2 \mathrm{~min}$ of extension at $72^{\circ} \mathrm{C}$ followed by $2 \mathrm{~min}$ of extension at $72^{\circ} \mathrm{C}$, followed by 15 cycles of denaturation at $98^{\circ} \mathrm{C}, 40 \mathrm{~s}$ of annealing at $66^{\circ} \mathrm{C}$, and $2 \mathrm{~min}$ of extension at $72^{\circ} \mathrm{C}$. This $\mathrm{dU}$ extension of the ORFs rendered them sensitive to uracil-DNA glycosylase (UDG). This two-step amplification protocol was developed after many optimization tests in which a large number of protocols, kits, and reagents for amplifying ORFs from high-GC genomes were evaluated. Using this protocol 5760 of the 6630 B. mallei ORFs were amplified (87\%) as high quality products (specific, correct molecular weight) of sufficient yield for LEE construction. ORF yields were quantified fluorimetrically using PicoGreen (Invitrogen). At least $1 \mathrm{pmol}$ of each ORF was generated for use in the library screen.

The cytomegalovirus (CMV) promoter and murine ubiquitin (UB) gene sequences $(1.3 \mathrm{~kb})$ and the human growth hormone $(\mathrm{hGH})$ gene terminator sequence $(0.6 \mathrm{~kb})$ from pCMVi-UB (Sykes and Johnston, 1999a) were amplified by PCR as two separate fragments, in bulk, with primers carrying dU stretches complementary to those present within the ORF end sequences. These sequencecompatible PCR fragments would serve as upstream and downstream elements for attachment to the ORFs. In preparation, the fragments were gel-fractionated and then purified from preparative agarose gels using QIAquick Gel extraction Kit (Qiagen), and stored at $-20^{\circ} \mathrm{C}$ until LEEs were ready to be non-covalently assembled.

In addition to this library of ORFs, two non $B$. mallei ORFs were similarly prepared in the two-step protocol for use in control group immunizations. The firefly luciferase (LUC) and human $\alpha 1$-antitrypsin gene (AAT) genes were amplified in the first step from pCMViLUC+ and pCMViAAT (Sykes and Johnston, 1999b).
The same universal primers described for the library were used in the second step amplification. The LUC and AAT-expressing LEEs would serve as irrelevant antigens for the challenge-protection assays; however, the LUC and AAT LEEs would also be positive controls for gene and genetic immunization activity, respectively. An extra group of mice were bombarded with the LUC-expressing LEEs prepared from the same batch of gene gun cartridges (bullets) as used for the immunizations. Mice were culled $24 \mathrm{~h}$ later and ears were harvested to assay LUC activity (Promega, Inc.; Svarovsky et al., 2008). The AAT-expressing LEE served as a positive control for genetic immunization efficiency, as immune sera was later tested for anti-AAT reactivity by ELISA (Sykes and Johnston, 1999b).

The genetic adjuvants heat-labile toxin subunit A (LTA) and subunit B (LTB) of E. coli were generated by cloning the respective subunit-encoding genes into the BglII and HindIII sites in the multi-cloning site of pCMVi (Sykes and Johnston, 1999a). LTA- and LTB-expressing covalently prepared LEEs containing the promoter, the LTA or LTB ORF, and terminator sequences were generated by digesting the pCMVi-LTA and pCMVi-LTB plasmids with DraI and PvuII. These enzymes serve to linearize the plasmid and cleave most of the plasmid backbone from the gene expression sequences. The LT-expressing LEE fragments were purified from the pCMVi backbone by fractionation using a size-exclusion (Sepharose) column. Fractions were analyzed on a $0.8 \%$ agarose gel to identify the LEE fragments, and these fractions were pooled. These plasmid sub-fragments were used for this large scale production of elements for the library of LEEs because large scale production of DNA by PCR is less efficient than that by standard plasmid production.

ORF POOLING, LEE ASSEMBLY, AND BIOLISTIC PARTICLE PREPARATION The 5760 B. mallei ORFs were concentration normalized and then pooled as ORFs using a two-dimensional $96 \times 48$ pool grid design, such that each dimension held all ORFs of the library. Therefore each ORF was present once per dimension and twice within the full grid. The ORFs within the X-dimension were partitioned into pools by a different sorting method than the ORFs in the Y-dimension such that each ORF resided in a pool of different co-resident ORFs within one dimension relative to the other and these pools were of different ORF complexities in one dimension relative to the other. Since the total DNA dose per gene gun bombardment (shot) was constant, the effect of altering the pool complexity was to alter the dose per ORF. The X-dimension pools delivered $10.5 \mathrm{fmol}$ of each ORF per shot and the Y-dimension pools delivered 5.25 fmole of each ORF per shot. This was accomplished as follows: The ORFs were arrayed into the B-G rows of 80 separate 96 -well plates. The $96 \mathrm{X}$-dimension pools were comprised of 60 ORF components that were pooled by taking all of the ORFs from a specific column from each of 10 plates (for example column 1 of plates $1-10 ; 1$ column/plate $\times 6$ ORFs/column $\times 10$ plates/pool $=60 \mathrm{ORFs} / \mathrm{pool})$. The $48 \mathrm{Y}$-dimension pools consisted of 120 ORFs that were pooled by taking all of the ORFs from a specific row from each of 10 plates (for example the $B$ row of plates $1-10 ; 1$ row $/$ plate $\times 12 \mathrm{ORF} /$ row $\times 10$ plates $/$ pool $=120$ ORFs/pool). Upstream and downstream expression elements were added to each pool to equimolar ratio to total 40.3 pmol ORFs per pool. The LTA and LTB adjuvant expressing ORFs were added to 
each pool in 1:9 ratio. The combined DNA mixtures representing each pool were ethanol precipitated, dissolved in water and $200 \mu \mathrm{l}$ aliquots $(3+1$ tubes $)$ were stores at $-20^{\circ} \mathrm{C}$ until genetic immunization was scheduled. UDG (NEB) treatment of DNA in each pool was performed immediately prior to the preparation of gene gun cartridges. For each mixture, 1.25 U of UDG enzyme was added per picomole of dU ends in pool (200 $\mathrm{U}$ for $200 \mu \mathrm{l}$ aliquot). Incubation of UDG reaction was carried out for $45 \mathrm{~min}$ at $37^{\circ} \mathrm{C}$ then $10 \mathrm{~min}$ at $60^{\circ} \mathrm{C}$ and cooling down to room temperature. The reaction mixtures were ethanol precipitated and dissolved in $100 \mu \mathrm{l}$ water.

For biolistic immunization, LEE pools were loaded onto positively charged (polyethyleneimine, PEI)-gold micro/nano particles as previously described (Svarovsky et al., 2008, 2009) and prepared onto gene gun cartridges for gene gun discharge.

\section{GENETIC IMMUNIZATION AND B. MALLEI CHALLENGE}

Female, 6- to 8-week-old, BALB/c mice (Harlan Sprague Dawley, Inc., Indianapolis, IN, USA) were acquired and housed under specific-pathogen-free-conditions with food and water ad libitum on a 12-h dark/light schedule for 1 week before use. The mice were organized into groups of eight mice genetically vaccinated in the ear skin pinnae with a Helios Gene Gun (Bio-Rad, Hercules, CA, USA) loaded with DNA coated gold particles (Svarovsky et al., 2009) and delivery at a helium pressure of 350 p.s.i. Two shots were delivered to each mouse, one in each ear. Genetic boosts with identical genetic inocula were administered at week 6 post-prime. Negative control mice were either unimmunized or immunized with a LEE expressing the irrelevant (non B. mallei) AAT antigen. Vaccine control mice were vaccinated with $0.5 \mu \mathrm{g}$ of $\mathrm{HK} B$. mallei [with Interleukin-12 (IL-12)] by intraparenteral (i.p.) injection using a 25 -gage syringe. Mice were challenged with $5 \times 10^{5} \mathrm{CFU} / 50 \mu \mathrm{l}$ of live B. mallei ( $\sim 2 \mathrm{LD}_{50}$ ) by intranasal (i.n.) delivery $12-13$ weeks following the boost. Aliquots from the inocula were plated to confirm the infecting dose. The challenge experiment was carried out in four cascaded sub-experiments due to animal housing limits; however, the same naïve, irrelevant LEE, and positive vaccine controls were included in each sub-experiment. All procedures and animal protocols used in this study were approved by the Biosafety and IACUC committees at UTMB and conducted in either BSL-3 or ABSL-3 laboratories. Survival of mice was monitored at $12 \mathrm{~h}$ intervals over time. Survival readouts were analyzed as detailed in the Section "Results." In the sub-experiment testing X1 through $\mathrm{X} 40$, no mice died from challenge including the unimmunized controls, indicating a sublethal dose had been administered. Since survival could not be scored as a valid readout for these groups, mice were sacrificed and lungs were weighed as a measure of the severity of inflammatory disease. Challenge results are provided in Table A1 in Appendix. Lung weight increase has been associated with increased disease (Huppert et al., 1976). However since these readouts could not be combined statistically with the survival data, these groups were excluded from the protection score grid analyses.

\section{RECOMBINANT PROTEIN PRODUCTION OF A SUBSET OF B. MALLEI CANDIDATES}

Cloning and protein expression protocols were followed as described previously (Whitlock et al., 2010). Briefly, target sequences were subjected to bioinformatics analysis using SignalP v.3.0 (Bendtsen et al., 2004), TMHMM v.2.0 (Krogh et al., 2001), and PHYRE v.0.2 (Kelley et al., 2009) to identify putative $\mathrm{N}$-terminal amino acid (AA) secretion sequences, transmembrane domains, and homologies to published crystal structures, respectively. Protein subcellular localization was predicted using PSORTb v.3.0.2 (Yu et al., 2010) and CELLO v.2.5 (Yu et al., 2004). Informatically predicted signal peptides and transmembrane sequences were identified so as to avoid them if possible in the design of the ORFs for cloning into bacterial expression constructs. This was intended to facilitate recombinant production. The redesigned ORFs were PCR-amplified from genomic $B$. mallei DNA and cloned into pET28a $(+)$ (Novagen), or pcDNA3.1 (Invitrogen) expression vector, in frame with either an $\mathrm{N}$ - or Cterminal $6 \times$ His affinity tag, or both. Oligo primers introducing specific restriction enzyme sites were purchased from Integrated DNA Technologies. In addition to the new targets, the GroEL gene (BMA_2001) was cloned to be produced and purified for use as a previously characterized immunogen (Amemiya et al., 2007).

For target protein production, E. coli host Rosetta ( $\lambda \mathrm{DE} 3)$ was transformed with the expression constructs. Expression was induced by growth in Overnight Express instant TB medium (Novagen) for 18-20 h. Bacterial pellets were lysed using $10 \times \mathrm{Cel}-$ Lytic B (Sigma), and $6 \times$ His-tagged proteins purified by $\mathrm{Ni}^{2+}$ affinity chromatography. Purified proteins were dialyzed against two changes of $10 \mathrm{mM}$ HEPES/150 mM NaCl, pH 7.4, aliquoted and stored at $-80^{\circ} \mathrm{C}$. Protein concentrations were determined using the BCA kit (Pierce) using bovine serum albumin (BSA) as a standard. Five of the 12 candidates and the previously identified antigen GroEL (hsp60) protein were sufficiently produced, with either an $\mathrm{N}$ - or C-terminal tag, or both, for vaccine testing. BMA_2001/GroEL (residues 1-550) and BMA_2821 (residues 418-753) were produced with both $\mathrm{N}$ - and C-terminal His tags. BMA_2804 (residues 17-370), BMA_A0768 (residues 20-489), and BMA_0816 were produced with C-terminal tags. BMA_0816 was produced in three sub-fragments (residues 43-334, 35-668, and 669-930) with C-terminal tags.

\section{PROTEIN IMMUNIZATION AND VACCINE TESTING OF INDIVIDUAL CANDIDATES}

Female, 6- to 8-week-old, BALB/c mice (groups of 12) were immunized by intramuscular (i.m.) injection with $10 \mu \mathrm{g}$ of one of the purified candidate or control proteins, each formulated with $12.5 \mu \mathrm{g}$ immune stimulating complexes (ISCOMs) AbISCO 100 (Isconova $\mathrm{AB}$, Sweden) and $12.5 \mu \mathrm{g}$ murine class $\mathrm{C}$ CpG motif oligos (ODN 2395; Coley Pharmaceuticals, Wellesley, MA, USA) in HEPES buffer ( $\mathrm{pH}$ 7.4). A negative control group was administered the adjuvants only. Mice were boosted at week 4 post-prime with identical inocula and then challenged at week 7 by i.n. route with $2 \mathrm{LD}_{50}\left(1 \times 10^{5}\right)$ B. mallei ATCC23344. Deaths were recorded twice daily. Survival results were analyzed by a log-rank statistic test; Mantel-Haenszel survival curves were generated and plotted (PRISM, Graphpad, Inc.). The results from the groups of mice immunized with the same antigen but with an $\mathrm{N}$ versus a $\mathrm{C}$ terminal tag were similar; therefore, these data were combined for analysis creating groups of 24 mice. The results from the $\mathrm{N}$ terminal and the central sub-proteins of BMA_816 were similarly protective (the C-terminal sub-protein conferred no protection); 
therefore, the results from these two groups were combined for analysis creating a group of 24 mice.

\section{BIOPLEX ANALYSES OF CYTOKINE AND CHEMOKINE EXPRESSION}

Peripheral blood sera levels of 23 cytokines and chemokines (IL-1 $\alpha$, IL-1 $\beta$, IL-2, IL-3, IL-4, IL-5, IL-6, IL-9, IL-10, IL-12p40, IL-12p70, IL-13, IL-17, Eotaxin, G-CSF, GM-CSF, IFN- $\gamma, \mathrm{KC}$, MCP-1, MIP- $1 \alpha$, MIP-1 $\beta$, RANTES, and TNF- $\alpha$ ) were determined using CD4 Pro Mouse Cytokine 23-plex Assay (Bio-Rad \#M60009RDPD). Blood samples from mice were collected 1 week prior to initial immunization (week -1) and 1 week after the second immunization (week 5 post-prime), and sera were analyzed as per manufacturer's instructions. Replicates of three animals per group per time point were used to determine cytokine and chemokine levels in the blood sera. An unpaired Student's $t$-test was used to evaluate significance $(p<0.05)$.

\section{RESULTS \\ DESIGN AND VALIDATION OF LINEAR EXPRESSION ELEMENTS FOR MURINE GENETIC IMMUNIZATIONS}

The B. mallei ATCC23344 genomic sequence was used to construct a library of 5760 unique ORFs for construction into LEEs. The upstream expression element carries both a CMV promoter and the short coding sequence of a mouse ubiquitin (UB) subunit for proteosome targeting and efficient antigen processing (Sykes and Johnston, 1999a). The downstream element carries a stop codon in all three frames and the efficient transcriptional terminator from hGH gene. The tripartite molecules are annealed to form functional LEEs (Figure 1 inset).

Before large scale library production, pilot constructs were prepared as described above in order to validate gene vaccine activity in mice. The genes encoding five B. mallei proteins

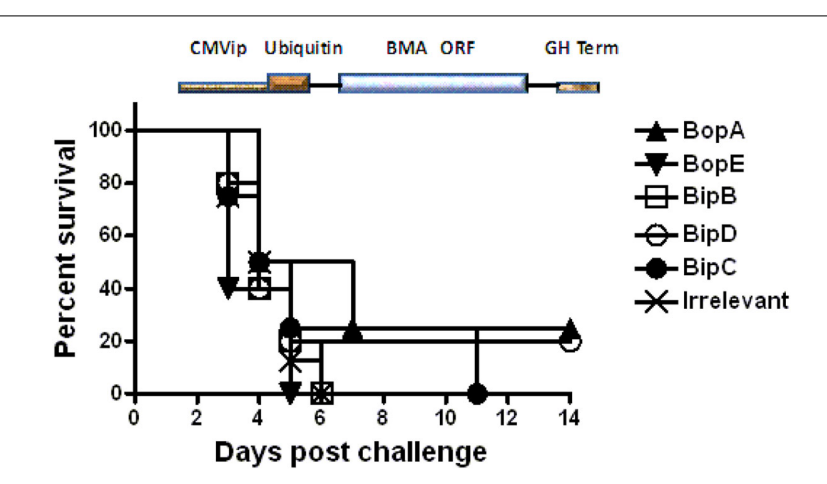

FIGURE 1 | Validation of ORF construction and expression in vivo. A set of five genes encoding $B$. mallei proteins predicted to be secreted were generated and constructed as linear expression elements (LEEs). These LEEs were constructed by the same protocols as intended for use in preparing and testing the $B$. mallei ORF library for vaccine candidates. Inset cartoon shows LEE design. These five LEEs were co-delivered with LEEs encoding the $E$. coli heat-labile enterotoxin subunits $A$ and $B(L T A / B)$ as adjuvant by gene gun at weeks 0,3 , and 6 into groups of five mice. At week 9 , mice were evaluated immunologically in challenge-protection assays. Survival curves of immunized animals are plotted following i.n. delivery of $1 \times 10^{5}$ bacteria (2 LD LD $_{5}$ B. mallei strain ATCC23344). The irrelevant group was immunized similarly but with a LEE expressing the luciferase (LUC) as a negative control for vaccine activity. This construct also served as a positive control for LEE gene expression activity (data not shown). predicted to be secreted via the type III secretion system (Whitlock et al., 2007) were used; one of these was recently tested as a protective antigen (Whitlock et al., 2010). BopA (BMA_A1521), BopE (BMA_A1523), BipD (BMA_A1528), BipC (BMA_A1530), and BipB (BMA_A1531) were constructed and prepared as LEEs for mammalian expression. They were individually delivered into groups of five mice by gene gun together with LEEs encoding both subunits A and B of E. coli lethal enterotoxin (LTA/B) as genetic adjuvant (Peppoloni et al., 2003). One control group was immunized with LEEs expressing the non-glanders (irrelevant) luciferase (LUC) antigen with LTA/B; another control group was not immunized. Mice were genetically immunized at weeks 0,3 , and 6 followed by blood draws for evaluation of sera reactivity to recombinantly produced antigens. At week 9, i.p. challenges with $6 \times 10^{7} \mathrm{~B}$. mallei were conducted. Survival results indicated several of the antigens conferred extended time to death; BopA and BipD provided 20\% endpoint survival from the i.p. challenge (Figure 1). These results confirm that the LEE genetic immunization constructs are immunologically functional in vivo.

\section{B. MALLEI EXPRESSION LIBRARY CONSTRUCTION AND STRATEGY FOR PROTECTIVE ANTIGEN SCREENING}

Bioinformatic analyses of the genome identified a number of challenges for gene production relative to standard PCR amplification, including the high-GC content (70\%) of the genome's coding sequences. In addition, several gene sequences displayed high homology; specific PCR amplification of these ORFs required detailed analyses of gene flanking sequences and individualized reaction conditions. Further design hurdles included the large number of transposable elements, bacterial introns, and overlapping transcripts that are found throughout the genome. Using the optimized reagents and protocol conditions, 5760 of the 6630 enumerated ORFs were amplified and constructed into LEEs, representing $87 \%$ of the coding capacity of $B$. mallei.

The ELI screen was designed to assay the vaccine potential of each B. mallei library component twice. This was done by distributing the complete library of 5760 ORFs into two immunization pools, by independent strategies that were designated $\mathrm{X}$ and $\mathrm{Y}$. The feasibility of performing this multiplexed protection experiment design for antigen discovery was previously demonstrated (Stemke-Hale et al., 2005; Borovkov et al., 2009). For this project, each of the X-pools held 60 ORFs, creating 96 X's; each of the Y-pools held 120 ORFs, creating 48 Y's. Every ORF resided once in the $\mathrm{X}$ library and once in the $\mathrm{Y}$ library, but at doses that differed by twofold. Unlike earlier strategies, this enabled sensitivity to be optimized in the X-dimension and screening efficiency to be optimized in the Y-dimension. Two-dimensional matrix analyses of these organized distributions of ORFs would enable a single animal experiment of 144 groups to be used to infer which individual ORFs were responsible for disease protection.

\section{GLANDERS ELI SCREEN}

The inocula comprising the $\mathrm{X}$ and $\mathrm{Y}$ LEE pools were co-delivered with the LTA/B genetic adjuvant into groups of eight BALB/C mice by gene gun on charged-gold micro/nanoparticles (Svarovsky et al., 2009). Genetic boosts were delivered at week 6 post-prime using the same inocula. At week 18 post-prime, a lethal i.n. challenge of B. mallei $\left(2 \mathrm{LD}_{50}\right)$ was administered; mice were monitored 
and deaths were recorded twice daily. As negative controls, naïve mice were not immunized and an irrelevant antigen group was administered an AAT-expressing LEE. As a positive control for protection, a group of mice was i.p. immunized with a HK B. mallei preparation with IL-12p70 as adjuvant.

Protection scores for all of the test and control groups were determined by recording the hours survived by each mouse, then deriving an average survival time for each group (Table A1). Confidence intervals (95\%) and ANOVA scores were calculated to generate corresponding $p$-values for each test group relative to controls. In the X library of ORF-expressing LEE pools, X57, X59, and X89 conferred significantly extended times to death; within the Y library pools Y15 and Y19 were significantly protective $(p<0.05)$. These results are detailed in Table 1 . In addition to the protection score analysis, log-rank Mantel-Haenszel survival curves were generated, with respective $p$-values calculated relative to controls (Prism 4.0, Graphpad Software, San Diego, CA, USA). This analysis indicated that mice immunized with pool Y24 also displayed significant extended time to death. Endpoint group survival rates are shown alongside each group's survival curve statistic in Table 1. Animals immunized with pool X89 showed 87.5\% endpoint survival following lethal i.n. infection. Immunization with pools X57 and X59 provided animals 75\% endpoint survival following the i.n. challenge. The mouse groups administered the positive vaccine control (HK B. mallei with IL-12p) displayed 100 and $62.5 \%$ survival rates in the $\mathrm{X}$ and $\mathrm{Y}$ challenge assays, respectively; the irrelevant antigen groups showed 25 and $0 \%$ survival in $\mathrm{X}$ and $\mathrm{Y}$ experiments, respectively. These survival curves are displayed in Figure 2; the top panel displays significantly different test group and also control group survival curves from the $\mathrm{X}$ challenge assay and the bottom panel similarly shows the $\mathrm{Y}$ challenge assay survival curves.

Together, the protection score and survival curve analyses indicated that three X-pools and three Y-pools were significantly protective. However, the pooling strategy of the two-dimensional screen designated Y-pools with twice the ORF complexity of the

Table 1 | Analyses of ELI challenge-protection screen.

\begin{tabular}{llll}
\hline & $\begin{array}{l}\text { Protection score } \\
\text { (p-value) }\end{array}$ & $\begin{array}{l}\text { Protection } \\
\text { rank }\end{array}$ & $\begin{array}{l}\text { Endpoint survival (\%) } \\
\text { (p-value) }\end{array}$ \\
\hline X-POOLS & & & \\
X89 & $423(0.003)$ & 1 & $87.5(0.006)$ \\
X57 & $372(0.03)$ & 2 & $75(0.029)$ \\
X59 & $365(0.04)$ & 3 & $75(0.05)$ \\
X75 & $321(0.17)$ & 4 & $62.5(0.137)$ \\
X95 & $318(0.18)$ & 5 & $62.5(0.158)$ \\
X76 & $317(0.20)$ & 6 & $62.5(0.156)$ \\
Irrelevant & $126(0.59)$ & & 25 \\
HK+ IL-12 & $456(0.0005)$ & & 100 \\
Y-POOLS & & & $50(0.027)$ \\
Y19 & $270(0.02)$ & 1 & $50(0.08)$ \\
Y15 & $269(0.02)$ & 2 & $37.5(0.05)$ \\
Y24 & $233(0.10)$ & 3 & 0 \\
Irrelevant & $146(0.89)$ & & 62.5 \\
HK+ IL-12 & $336(0.0003)$ & &
\end{tabular}

X-pools (120 versus 60 ORFs). Since a matrix analysis would be most informative if a similar number of ORFs were crossed from each dimension (library), the X-pools ranked 4, 5, and 6 (X75, $\mathrm{X} 76$, and X95 with $p$-values of $0.17,0.20$, and 0.018 , respectively) were taken into the cross-hair analyses. Their protection scores, survival rates, and statistics are provided in Table 1.

\section{IDENTIFICATION AND TESTING OF SCREEN-INFERRED PROTECTIVE ANTIGENS}

A matrix analysis was performed to pinpoint any antigens that conferred protection as a constituent within both its X-pool and Y-pool inocula. This was done by comparing the list of ORFs comprising the subset of X-pools selected for further evaluation

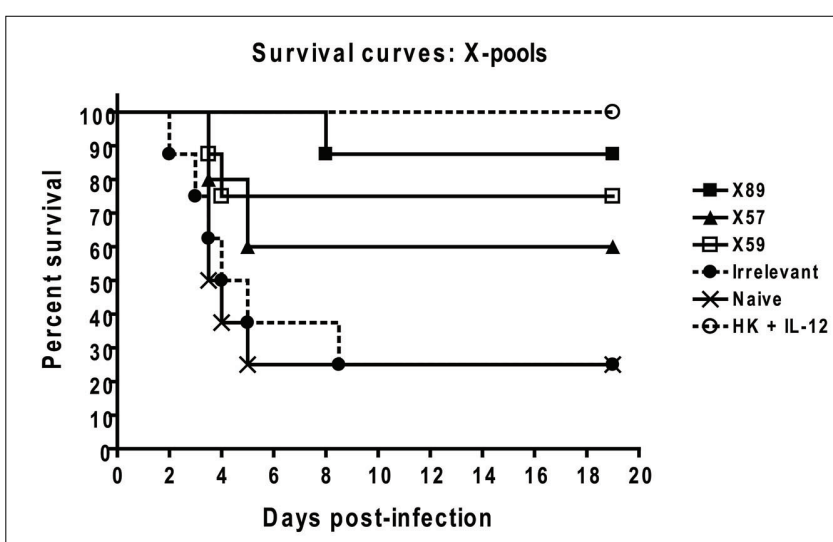

Survival curves: Y-pools

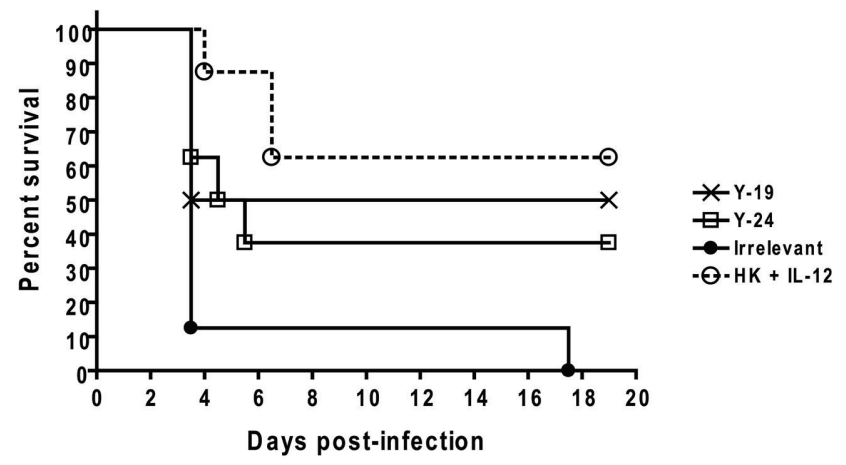

FIGURE 2 | Screening of the B. mallei ORF-ome for vaccine candidates by ORF-pool immunization and challenge-protection assay. Groups of eight mice were immunized once in each ear pinna with $1 \mu \mathrm{g}$ dose by gene gun. Each discharge carried a pool of $B$. mallei ORFs as LEEs $(0.9 \mu \mathrm{g})$ and the genetic adjuvant LTA/B $(0.1 \mu \mathrm{g})$. The LTA and LTB-expressing LEEs were mixed 1:5 (0.08 and $0.02 \mu \mathrm{g}$, respectively). Two libraries of $5750 \mathrm{ORFs,}$ labeled $X$ and $Y$, were partitioned into 96 pools of $60 \mathrm{ORFs}$ (X-pools) or 48 pools of 120 ORFs (Y-pools). Controls were heat-killed (HK) B. mallei, the non $B$. mallei antigen $\alpha 1$-antitrypsin (AAT), and naïve mice. Boosts were similarly administered at week 6 . A $2 \operatorname{LD}_{50}\left(1 \times 10^{5}\right)$ dose of live $B$. mallei ATCC23344 was administered i.n. at week 10 and death was monitored twice daily. Survival curves were generated for all groups; however, only the curves corresponding to statistically protective groups $(p<0.05)$ and controls are plotted for clarity. Top graph displays results from animals immunized with protective pools from the X library. Bottom graph displays the survival courses of mouse groups administered the protective pools from the $Y$ library. 
to the list of ORFs comprising the Y-pools selected for evaluation. Furthermore, each ORF was considered to represent its full length target gene. This was done because a protective antigen often carries multiple protective epitopes (Crowe et al., 2010), and these are likely to rank differently in potency from one species to another as a result of divergent antigen presentation molecules and processes. Therefore, identification of any portion of a gene is likely to indicate a useful target antigen, as opposed to merely a target epitope. Twelve B. mallei genes were identified by this overlapping pool matrix analysis. These candidates are enumerated in Table 2 along with their resident pools within the screen and any predicted protein functions or homologies found in existing databases.

To evaluate how genetic immunization leads might translate into more conventional protein subunit vaccine formulations, the 12 new gene vaccine candidates were subjected to structural analysis in preparation for testing in a new round of challengeprotection assays as individually administered protein inocula. Many of the target proteins carried multiple predicted transmembrane helices that would make recombinant protein production difficult. These were excluded from the expression constructs in favor of regions predicted to be immunogenic (see Materials and Methods). The BMA_0816 gene was cloned and expressed as three sub-fragments because of its large size. Five candidates (BMA_A0712,BMA_A0768, BMA_0816, BMA_2804, BMA_2821) and the previously described immunogen GroEL (BMA_2001; Amemiya et al., 2007) were bacterially produced with $\mathrm{N}$ - and/or C-terminal His tags and purified by standard nickelaffinity chromatography. Each of the six proteins was delivered i.m. with ISCOMs and murine class $\mathrm{C}$ motif $\mathrm{CpG}$ oligos as adjuvant into groups of $12 \mathrm{BALB} / \mathrm{c}$ mice. Boosts were administered at

Table 2 | Individual B. mallei vaccine candidate genes identified from matrix analysis of the ELI challenge-protection assays.

\begin{tabular}{|c|c|c|}
\hline $\begin{array}{l}\text { ELI-derived } \\
\text { vaccine } \\
\text { candidate }\end{array}$ & Predicted function/homology & $\begin{array}{l}\text { Resident } \\
\text { ELI pools }\end{array}$ \\
\hline BMA_A1219 & Tetratricopeptide repeat protein & X95; Y24 \\
\hline BMA_A1678 & $\begin{array}{l}\text { Selenocysteine-specific translation } \\
\text { elongation factor }\end{array}$ & $\begin{array}{l}X 76 ; \times 95 \\
\text { Y24 }\end{array}$ \\
\hline BMA_A1678 & Putative CpaE protein (pilus assembly) & $\mathrm{X} 76 ; \mathrm{Y} 24$ \\
\hline BMA_A1325 & Major facilitator family sugar transporter & X95; Y24 \\
\hline BMA_A0712 ${ }^{1}$ & Major facilitator superfamily protein & $X 75 ; Y 24$ \\
\hline BMA_A0768 ${ }^{2}$ & Mannitol dehydrogenase family protein & $X 57 ; Y 19$ \\
\hline BMA_A0950 & $\begin{array}{l}\text { Major facilitator family transporter; MerR } \\
\text { family transcriptional regulator }\end{array}$ & X89;Y24 \\
\hline BMA_2821 2 & $\begin{array}{l}\text { Toxin secretion ABC transporter, ATP-binding } \\
\text { protein (colicinV processing peptidase) }\end{array}$ & $\mathrm{X} 75 ; \mathrm{Y} 15$ \\
\hline BMA_2804 ${ }^{1}$ & Molecular chaperone, Hsp70 & $X 75 ; Y 19$ \\
\hline BMA_2468 & $\begin{array}{l}\text { Glyceraldehyde-3-phosphate dehydrogenase, } \\
\text { type I }\end{array}$ & $X 57 ; Y 24$ \\
\hline BMA_0092 & Peptide ABC transporter, ATP-binding protein & $X 59 ; Y 24$ \\
\hline BMA_0816 ${ }^{2}$ & $\begin{array}{l}\text { Maltooligosyl trehalose synthase (putative } \\
\text { glycosyl hydrolase) }\end{array}$ & $\mathrm{X} 89 ; Y 24$ \\
\hline
\end{tabular}

${ }^{1}$ Candidates tested individually are shown in boldface.

${ }^{2}$ Vaccine candidates found to be protective are indicated in red type. week 4 and then the mice were challenged with live B. mallei (2 $\left.\mathrm{LD}_{50}\right)$ at week 7 . Survival was monitored and recorded twice daily.

Protection was assessed by generating Mantel-Haenszel survival curves and deriving a log-rank statistic as described above. The results plotted in Figure 3 show that three of the five tested candidates and GroEL were confirmed as conferring partial protection. Immunization with the protein encoded by BMA_A0768 provided 25\% (3/12) endpoint survival while GroEL immunization provided $12.5 \%$ (3/24) endpoint survival and both displayed significantly extended times to death $(p=0.025$ and $p<0.001$, respectively). The proteins encoded by BMA_2821 and BMA_0816 also conferred significantly extended times to death ( $p=0.0023$ and $p<0.0001$, respectively) relative to adjuvant only immunized controls. The three significantly protective candidates (BMA_A0768,BMA_2821, and BMA_0816) are highlighted in red in Table 2.

\section{ELI VACCINE CANDIDATES ELICIT SERUM CYTOKINE AND CHEMOKINE RESPONSES}

Blood was drawn from the animals described above, immunized with the five $B$. mallei protein antigen candidates or the adjuvant control, 1 week prior to immunization (week -1 relative to prime) as a baseline for each animal and then 1 week after the booster (= week 5 post-prime) as a measure of vaccine elicited responses. Measuring levels at these two time points was designed to display a profile of the hosts' responses to vaccination (Figure 4). The influence of the adjuvant on host responses was measured by comparing the pre-immunization profiles to that of the control sera, which was not drawn from naïve mice but from mice immunized with adjuvant only. Prior to immunization, GM-CSF (BMA_0768) and MIP-1 $\beta$ (BMA_0768) showed elevated levels relative to the adjuvant-immunized control sera; whereas IL-12p70 (BMA_A0712) was significantly lower in one of the pre-immune

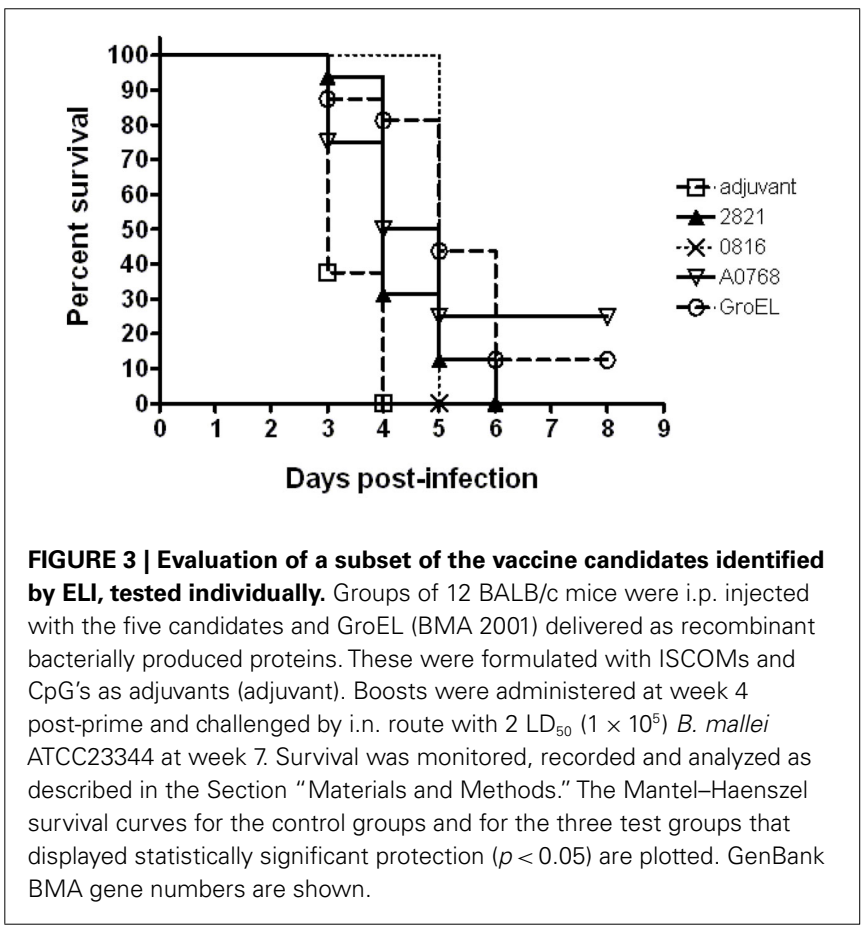


A

Pre-immunization

Post-immunization
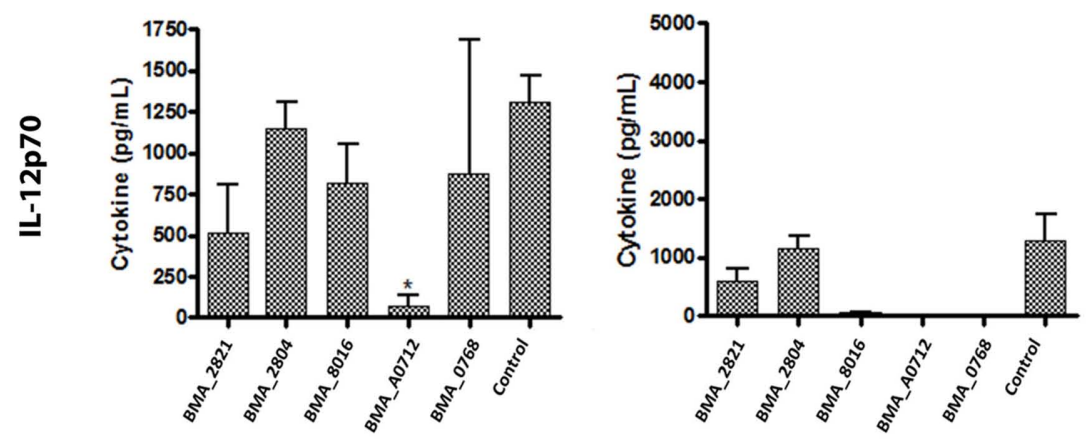

B
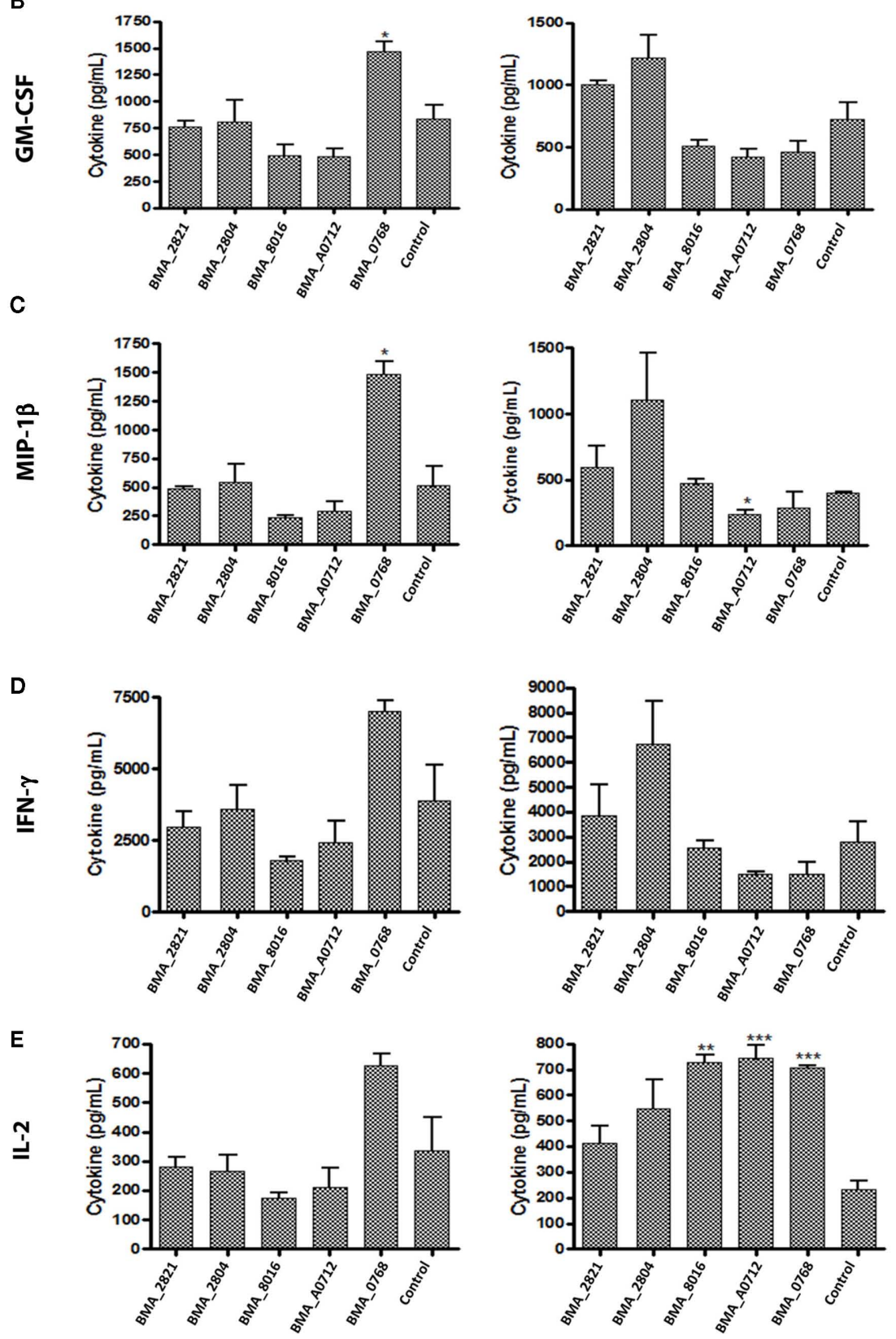


\section{Pre-immunization}

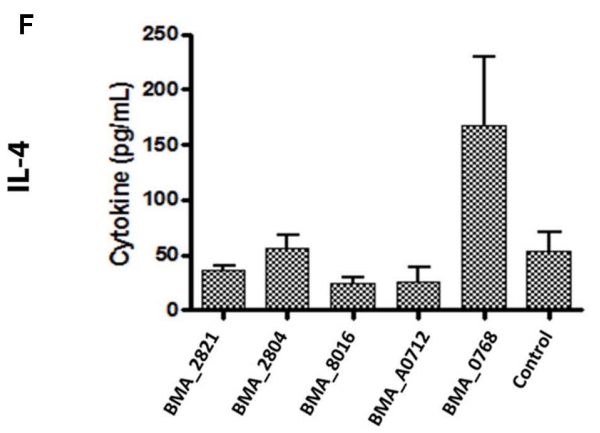

G

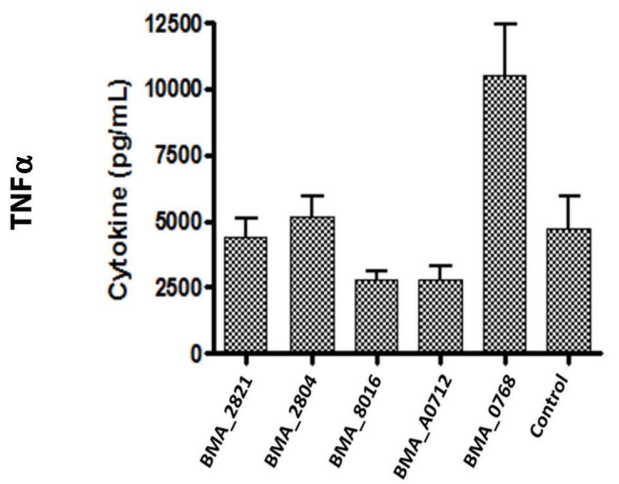

Post-immunization
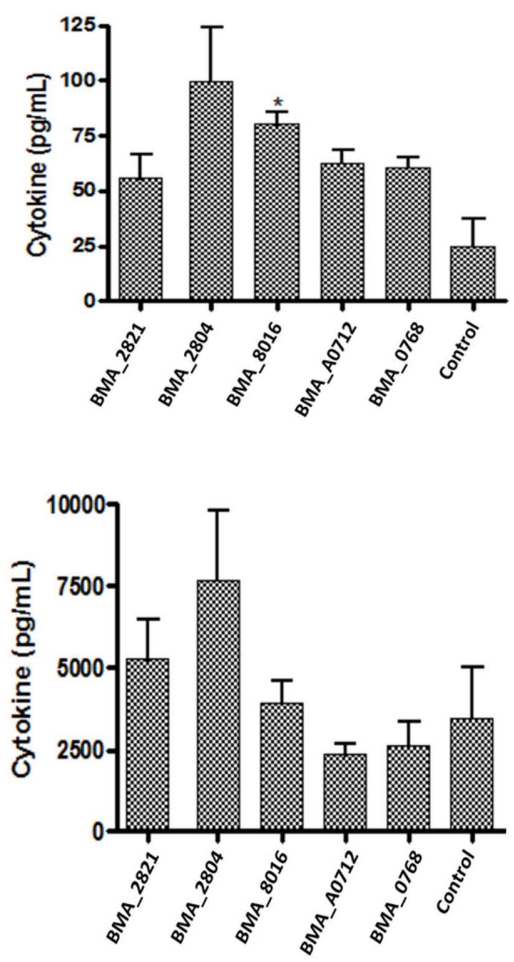

FIGURE 4 | Bioplex analyses of proinflammatory cytokines elicited in peripheral blood of immunized versus unimmunized mice. Blood was drawn (i) 1 week prior to immunization and (ii) 1 week post booster immunization ( $=5$ weeks post-prime) of the mice described in Figure 3. Results from these time points are graphed on the left (pre-immunization) and right (post-immunization) panels. Control sera were drawn from adjuvant-immunized mice. Replicates of three animals per group per time point were used to determine the level of cytokine or chemokine indicated above each pair of graphs (A) through (G). Sera were collected and analyzed per manufacturer's instructions. Unpaired Student's $t$-test was utilized to determine significance $(p<0.05)$. Error bars are SD with group sera. sera groups relative to the sera from adjuvant expose mice. This indicates that IL-12p70 may be elicited by the ISCOM and CpG formulation alone. Post-immunization, IL-2 levels were significantly elevated in sera from mice immunized with three of the five antigen candidates (BMA_0816, BMA_A0712, BMA_0768), two of which were protective (Figure 3). IL-4 (BMA_0816) and MIP-1 $\beta$ (BMA_A0712) were also significantly different $(p<0.05)$ from the adjuvant-immunized control sera levels, with IL-4 elevated and MIP- $1 \beta$ reduced. These levels represent antigen-specific activity elicited by the vaccine candidates.

\section{DISCUSSION}

A functional genomics vaccine candidate screen does not need to assume anything about the properties or characteristics of protective antigens. However the screen presented here does assume that a protective gene can be detected among many simultaneously expressed ones. Support for this assumption lies in its parallel with the antigenic complexity of a live or whole-pathogen vaccine, or a pathogen infection, situations in which the immune system is exposed to a mixture of many antigens. We used ELI to directly test the $B$. mallei ORF-eome for protective components by genetic immunization followed by lethal challenge. A two-dimensional, matrix analysis of a genomic-scale protection assay following vaccination with pools of ORFs indicated 12 gene candidates as being responsible for conferring survival rates as high as $\sim 90 \%$ against i.n. challenges. Five of these 12 vaccine candidates were produced as proteins and tested as individual antigens in the challenge-protection assays; three were found to provide significant, partial protection from a lethal pulmonary infection with $B$. mallei.

The protection level measured following immunization with any of the five tested protein candidates was lower than that achieved by the ORF pools in which the candidates were originally resident. The simplest explanation for this outcome is that the more highly protective candidates were among the seven untested of the 12 matrix-inferred candidates. Even for the five tested candidates, only the portions of the target proteins selected for recombinant expression by bioinformatics were administered; more strongly protective epitopes may have been unintentionally excluded. Alternatively the antigen delivery format, which differed between the two rounds of challenge-protection assays, may be critical. First, the genetic immunization constructs expressed the antigens endogenously within the skin cells of the host, and these constructs carried proteasomal targeting (UB) sequences intended to promote cellular immune responses against the UB-fused antigen. By contrast, the candidates were redesigned in the second 
round without UB fusion or their natural secretory leader peptides for ex vivo protein production. We had elected to reformulate the candidates from genes into proteins for the secondary round of vaccine testing because of the generally higher level of acceptance of this more traditional subunit vaccine format. Namely, several protein-based vaccines have already been FDA approved (http://www.fda.gov/BiologicsBloodVaccines/Vaccines/Approved Products/UCM093833) while gene vaccines are at this time still in trials. Protein formats have been shown to promote $\mathrm{T}$ helper cell 2-like (Th2) responses and antibody production, relative to in vivo produced antigen (Chow et al., 1998; Iborra et al., 2007). These responses may not be as protective as Th1 responses against B. mallei. As a second difference in delivery format between the two rounds, the mixed versus individual context of the antigen may be relevant. The significance of this format distinction is consistent with several previous ELI screens in which all candidates were tested, and all tested as genes in both initial and secondary screens. In these studies, the mixed pool inocula were frequently more protective than the individually evaluated candidates (Stemke-Hale et al., 2005; Li et al., 2006; Borovkov et al., 2009), as found in this work.

We suggest that the complexity of the ORF pools is important. In this project, we intentionally designed a grid with differing complexities (either 60 or 120 in the X and Y-pools respectively) potentially capturing the undetermined effects of antigen dose, complexity, and competition on immunity. If there were neither negative nor positive interactions among the constituents of the mixed inocula, then we anticipated that maximizing dose would be most important in maximizing any response elicited. Since we delivered constant total genetic doses, this would mean that the lower pool complexity (higher individual ORF doses) of the Xpools would be advantaged over the Y-pools. However the average levels of protection conferred by the $\mathrm{X}$ versus the $\mathrm{Y}$-pools, relative to HK B mallei and irrelevant antigens were similar. This indicates that dose was not a strong factor in the survival readout. Alternatively, if immunological interactions do occur among the pool constituents, then an ORF's individual performance level may be evaluated relative to that within a pool; however, the performance of an ORF in two different pools of two different complexities cannot be quantitatively interpreted. Antigenic competition has been well described among co-delivered protein antigens (Adorini et al., 1989); however, a range of results have been reported for immune interactions among co-delivered genetic antigens (Braun et al., 1998; Sedegah et al., 2004; Hirao et al., 2011). A combination of competitive and cooperative activities among the antigen pool components would have opposing effects that would blur minor differences in antigen dose. This is consistent with our observations. Nonetheless, the performance of both the $\mathrm{X}$ and $\mathrm{Y}$ antigen pools were reproducibly superior relative to that of the individually administered antigens. These results suggest that the overarching effect of gene vaccine complexity is cooperative. The three confirmed individual candidates may play a critical role as a specific antigen, while one or more of the remaining constituents of their highly protective resident pools may provide non-specific, or even additional specific, immunological help and modulation. This may be addressed in vaccine development in a number of ways. For example, a small set of cooperatively acting components may be identified in future studies that are highly effective. Protection levels may also be enhanced by immunomodulators that direct responses to those determined to be most effective. Mixed modality immunization regimens such as DNA-prime/protein- or live vectored-boosts may serve to widen the breadth of responses to facilitate greater protection levels. Notably, the ELI screen was done by genetic immunization and a long immunization regimen (18 weeks), whereas the individual components were delivered as proteins in an abbreviated regimen ( 7 weeks). Perhaps their combination in a mixed modality prime-boost regimen, and an extended immunization period, would be productive.

Bioplex determinations of a set of 23 cytokine and chemokines identified IL-2 as the principal cytokine elicited by the vaccine candidates. IL-2 was significantly elevated relative to controls in the sera from three of the five groups of mice immunized with individual protein antigens; two of these groups displayed significant protection from challenge. IL- 4 was also significantly elevated in sera from mice immunized with one of the tested candidates that conferred protection. Notably, the cytokine profile elicited by these subunit vaccines is divergent from those stimulated following exposure to HK B. mallei, or the BopA subunit, which includes IFN $\gamma$ and TNF $\alpha \tau$ cell secretion (Whitlock et al., 2008, 2010). This suggests that improved protection might be achieved by either formulating these antigens with a different adjuvant or preparing the antigens in another format (such as genes or gene pools, or live vector) that would modulate the cytokine profile closer to that elicited by other vaccines. However, the strong CD4 T cell and antibody response indicated by expression of IL-2 and IL-4 is consistent with the importance found for B cells in the protective response to HK B. mallei (Whitlock et al., 2008). Notably, class $\mathrm{C}$ motif $\mathrm{CpG}$ oligos were selected as the adjuvant in this study because of the role demonstrated for antibodies in addition to cell-mediated responses in clearing B. mallei infections (Bondi and Goldberg, 2008). A more divergent explanation is that these three new antigens direct the host immune system to generate a unique protective response not engendered by previously tested subunits or by the pathogen itself.

In the microbial world, the genomes of Burkholderia species rank as some of the most complex, carrying nearly as many base pairs as a eukaryotic yeast genome (Holden et al., 2004; Nierman et al., 2004). Through the empirical discovery approach described here, we have identified 12 new vaccine candidates for further evaluation (Table 2). A number of these pathogen components were unlikely to have been selected informatically from the genome since the pSORT B-predictions indicated cytoplasmic localizations (Table 3). The preliminary testing of a subset of only five of these candidates established that three conferred significant protection against a pulmonary challenge with virulent $B$. mallei bacilli. Of these three protective candidates, two are predicted to encode cytoplasmic enzymes. First, BMA_A0768 displays homology to a mannitol dehydrogenase (MTD) gene, encoding a member of an oxidoreductase family. Mannitol and MTD are known to play roles in host defense and pathogen counter-defense (Jennings et al., 1998). Second, BMA_0816 is homologous to a maltooligosyl trehalose synthase gene, encoding an enzyme that catalyzes transglycosylations (Nakada et al., 1995). In contrast to these genes, the third vaccine candidate, BMA_2821, encodes a membrane protein. It shows homology to a member of the ATPbinding cassette $(\mathrm{ABC})$ transporter family that secretes the peptide 
Table 3 | Characteristics of individually protective subunit vaccine candidates.

\begin{tabular}{|c|c|c|c|}
\hline $\begin{array}{l}\text { B. mallei } \\
\text { vaccine } \\
\text { candidate }\end{array}$ & $\begin{array}{l}\text { Cellular } \\
\text { location }\end{array}$ & $\begin{array}{l}\text { Percentage } \\
\text { identity to } \\
\text { Bpm } 96243\end{array}$ & $\begin{array}{l}\text { Survival curve } \\
\text { significance, } \\
p \text {-value }\end{array}$ \\
\hline BMA_A0768 & Cytoplasmic ${ }^{a, b}$ & 99.8 & 0.025 \\
\hline BMA_2821 & Inner membrane $e^{a, b}$ & 99.7 & 0.002 \\
\hline BMA_0816 & $\begin{array}{l}\text { Cytoplasmic }{ }^{a, b} / \text { outer } \\
\text { membrane }^{b}\end{array}$ & 99.5 & $<0.0001$ \\
\hline
\end{tabular}

a Determined by PSORTb v.3.0.2.

${ }^{b}$ Determined by CELLO v.2.5.

antibiotic colicinV (Zhong et al., 1996). Colicin is encoded on a virulence plasmid and the $\mathrm{ABC}$ efflux transporter secretes it (Waters and Crosa, 1991). By conventional criteria, this surface-located virulence-factor secreting protein might have been classified as a putative protective antigen. Notably, another ABC transporter was within the set of 12 ELI-derived candidates, in addition to a sugar transporter; however, neither of these ORFs (BMA_0092 and BMA_A1325, respectively) was individually tested in the vaccine assay.

Sequence alignments of the protective $B$. mallei ORFs to the B. pseudomallei K96243 (Bpm 96243) strain homologs show a very high percentage of identity (Table 3 ), suggesting that these antigens may be able to cross-protect against B. pseudomallei infection. Further characterization and optimizations of the protective immune responses induced by these new candidates, and exploration of the remaining candidates, may reveal novel pathways to immunity against $B$. mallei, and possibly $B$. pseudomallei. In summary our results provide a basis for the development of a safe and effective Burkholderia vaccine, comprised of a set of genome-encoded pathogen components, against pulmonary glanders disease.

\section{AUTHOR CONTRIBUTIONS}

Kathryn F. Sykes, Alfredo G. Torres, and D. Mark Estes designed the research project; Gregory C. Whitlock, Mark D. Robida, Barbara M. Judy, Arpaporn Deeraksa, Katherine Taylor, C. Shane Massey, Andrey Loskutov, Alex Y. Borovkov, Jose A. Cano, and Kevin Brown executed the experiments and contributed to the analyses of results; Omar Qazi and Katherine A. Brown designed and produced critical reagents; Kathryn F. Sykes drafted the manuscript, and all authors contributed to the manuscript review and final preparation.

\section{ACKNOWLEDGMENTS}

These studies were supported by NIAID/NIH grant U54 AI 057156 from the Western Regional Center of Excellence for Biodefense. The contents are solely the responsibility of the authors and do not necessarily represent the official views of the RCE Programs Office, NIAID, or NIH. The authors would like to sincerely thank many members of the Center for Innovations of Medicine at ASU and the Departments of Microbiology and Immunology and Pathology at the University of Texas Medical Branch for collectively a very significant contribution to this research effort.

\section{REFERENCES}

Adorini, L., Appella, E., Doria, G., Cardinaux, F., and Nagy, Z. A. (1989). Competition for antigen presentation in living cells involves exchange of peptides bound by class II MHC molecules. Nature 342, 800-803.

Amemiya, K., Bush, G. V., Deshazer, D., and Waag, D. M. (2002). Nonviable Burkholderia mallei induces a mixed Th1- and Th2-like cytokine response in $\mathrm{BALB} / \mathrm{c}$ mice. Infect. Immun. 70, 2319-2325.

Amemiya, K., Meyers, J. L., Deshazer, D., Riggins, R. N., Halasohoris, S., England, M., Ribot, W., Norris, S. L., and Waag, D. M. (2007). Detection of the host immune response to Burkholderia mallei heat-shock proteins GroEL and DnaK in a glanders patient and infected mice. Diagn. Microbiol. Infect. Dis. 59, 137-147.

Barry, M. A., Lai, W. C., and Johnston, S. A. (1995). Protection against mycoplasma infection using expression-library immunization. Nature 377, 632-635.

Bendtsen, J. D., Nielsen, H., Von Heijne, G., Brunak, S., Bendtsen, J. D., Nielsen, H., Von Heijne, G., and
Brunak, S. (2004). Improved prediction of signal peptides: signalP 3.0. J. Mol. Biol. 340, 783-795.

Bondi, S. K., and Goldberg, J. B. (2008). Strategies toward vaccines against Burkholderia mallei and Burkholderia pseudomallei. Expert Rev. Vaccines 7, 1357-1365.

Borovkov, A., Magee, D. M., Loskutov, A., Cano, J. A., Selinsky, C., Zsemlye, J., Lyons, C. R., and Sykes, K. (2009). New classes of orthopoxvirus vaccine candidates by functionally screening a synthetic library for protective antigens. Virology 395, 97-113.

Braun, R., Babiuk, L. A., and Van Drunen Littel-Van Den, H. (1998). Compatibility of plasmids expressing different antigens in a single DNA vaccine formulation. J. Gen. Virol. 79(Pt 12), 2965-2970.

Chow, Y. H., Chiang, B. L., Lee, Y. L., Chi, W. K., Lin, W. C., Chen, Y. T., and Tao, M. H. (1998). Development of Th1 and Th2 populations and the nature of immune responses to hepatitis B virus DNA vaccines can be modulated by codelivery of various cytokine genes. J. Immunol. 160, 1320-1329.
Crowe, S. R., Ash, L. L., Engler, R. J., Ballard, J. D., Harley, J. B., Farris, A. D., and James, J.A. (2010). Select human anthrax protective antigen epitopespecific antibodies provide protection from lethal toxin challenge. $J$. Infect. Dis. 202, 251-260.

Cui, J., Han, L. Y., Cai, C. Z., Zheng, C. J., Ji, Z. L., and Chen, Y. Z. (2005). Prediction of functional class of novel bacterial proteins without the use of sequence similarity by a statistical learning method. J. Mol. Microbiol. Biotechnol. 9, 86-100.

Elschner, M. C., Scholz, H. C., Melzer, F., Saqib, M., Marten, P., Rassbach, A., Dietzsch, M., Schmoock, G., De Assis Santana, V. L., De Souza, M. M., Wernery, R., Wernery, U., and Neubauer, H. (2011). Use of a Western blot technique for the serodiagnosis of glanders. BMC Vet. Res. 7, 4 . doi:10.1186/1746-6148-7-4

Hirao, L. A., Draghia-Akli, R., Prigge, J. T., Yang, M., Satishchandran, A., Wu, L., Hammarlund, E., Khan, A. S., Babas, T., Rhodes, L., Silvera, P., Slifka, M., Sardesai, N. Y., and Weiner, D. B. (2011). Multivalent smallpox DNA vaccine delivered by intradermal electroporation drives protective immunity in nonhuman primates against lethal monkeypox challenge. J. Infect. Dis. 203, 95-102.

Holden, M. T., Titball, R. W., Peacock, S. J., Cerdeno-Tarraga, A. M., Atkins, T., Crossman, L. C., Pitt, T., Churcher, C., Mungall, K., Bentley, S. D., Sebaihia, M., Thomson, N. R., Bason, N., Beacham, I. R., Brooks, K., Brown, K. A., Brown, N. F., Challis, G. L., Cherevach, I., Chillingworth, T., Cronin, A., Crossett, B., Davis, P., Deshazer, D., Feltwell, T., Fraser, A., Hance, Z., Hauser, H., Holroyd, S., Jagels, K., Keith, K. E., Maddison, M., Moule, S., Price, C., Quail, M. A., Rabbinowitsch, E., Rutherford, K., Sanders, M., Simmonds, M., Songsivilai, S., Stevens, K., Tumapa, S., Vesaratchavest, M., Whitehead, S., Yeats, C., Barrell, B. G., Oyston, P. C., Parkhill, J., Holden, M. T. G., Titball, R. W., Peacock, S. J., CerdenoTarraga, A. M., Atkins, T., Crossman, L. C., Pitt, T., Churcher, C., Mungall, K., Bentley, S. D., Sebaihia, M., Thomson, N. R., Bason, N., Beacham, I. R., Brooks, K., Brown, K. A., Brown, N. F., Challis, G. L., Cherevach, I., Chillingworth, T., Cronin, A., Crossett, B., Davis, P., 
Deshazer, D., Feltwell, T., Fraser, A., Hance, Z., Hauser, H., Holroyd, S., Jagels, K., Keith, K. E., Maddison, M., Moule, S., Price, C., Quail, M. A., Rabbinowitsch, E., Rutherford, K., Sanders, M., Simmonds, M., Songsivilai, S., Stevens, K., Tumapa, S., Vesaratchavest, M., Whitehead, S., Yeats, C., Barrell, B. G., Oyston, P. C. F., and Parkhill, J. (2004). Genomic plasticity of the causative agent of melioidosis, Burkholderia pseudomallei. Proc. Natl. Acad. Sci. U.S.A. 101, 14240-14245.

Huppert, M., Sun, S. H., GleasonJordon, I., and Vukovich, K. R. (1976). Lung weight parallels disease severity in experimental coccidioidomycosis. Infect. Immun. 14, 1356-1368.

Iborra, S., Abanades, D. R., Parody, N., Carrion, J., Risueno, R. M., Pineda, M. A., Bonay, P., Alonso, C., and Soto, M. (2007). The immunodominant $\mathrm{T}$ helper 2 (Th2) response elicited in BALB/c mice by the Leishmania LiP2a and LiP2b acidic ribosomal proteins cannot be reverted by strong Thl inducers. Clin. Exp. Immunol. 150, 375-385.

Jennings, D. B., Ehrenshaft, M., Pharr, D. M., and Williamson, J. D. (1998). Roles for mannitol and mannitol dehydrogenase in active oxygenmediated plant defense. Proc. Natl. Acad. Sci. U.S.A. 95, 15129-15133.

Kelley, L. A., Sternberg, M. J., Kelley, L. A., and Sternberg, M. J. E. (2009). Protein structure prediction on the web: a case study using the Phyre server. Nat. Protoc. 4, 363-371.

Kenny, D. J., Russell, P., Rogers, D., Eley, S. M., and Titball, R. W. (1999). In vitro susceptability of Burkholderia malle $i$ in comparison to those of other pathogenic Burkholderia spp. Antimicrob. Agents Chemother. 43, 2773-2775.

Krogh, A., Larsson, B., Von Heijne, G., and Sonnhammer, E. L. (2001). Predicting transmembrane protein topology with a hidden Markov model: application to complete genomes. J. Mol. Biol. 305, 567-580.

Leelarasamee, A. (2004). Recent development in melioidosis. Curr. Opin. Infect. Dis. 17, 131-136.

Li, D., Borovkov, A., Vaglenov, A., Wang, C., Kim, T., Gao, D., Sykes, K. F., Kaltenboeck, B., Li, D., Borovkov, A., Vaglenov, A., Wang, C., Kim, T., Gao, D., Sykes, K. F., and Kaltenboeck, B. (2006). Mouse model of respiratory Chlamydia pneumoniae infection for a genomic screen of subunit vaccine candidates. Vaccine 24 , 2917-2927.
Nakada, T., Maruta, K., Tsusaki, K., Kubota, M., Chaen, H., Sugimoto, T., Kurimoto, M., and Tsujisaka, Y. (1995). Purification and properties of a novel enzyme, maltooligosyl trehalose synthase, from Arthrobacter sp. Q36. Biosci. Biotechnol. Biochem. 59, 2210-2214.

Nierman, W. C., Deshazer, D., Kim, H. S., Tettelin, H., Nelson, K. E., Feldblyum, T., Ulrich, R. L., Ronning, C. M., Brinkac, L. M., Daugherty, S. C., Davidsen, T. D., Deboy, R. T., Dimitrov, G., Dodson, R. J., Durkin, A. S., Gwinn, M. L., Haft, D. H., Khouri, H., Kolonay, J. F., Madupu, R., Mohammoud, Y., Nelson, W. C., Radune, D., Romero, C. M., Sarria, S., Selengut, J., Shamblin, C., Sullivan, S. A., White, O., Yu, Y., Zafar, N., Zhou, L., Fraser, C. M., Nierman, W. C., Deshazer, D., Kim, H. S., Tettelin, H., Nelson, K. E., Feldblyum, T., Ulrich, R. L., Ronning, C. M., Brinkac, L. M., Daugherty, S. C., Davidsen, T. D., Deboy, R. T., Dimitrov, G., Dodson, R. J., Durkin, A. S., Gwinn, M. L., Haft, D. H., Khouri, H., Kolonay, J. F., Madupu, R., Mohammoud, Y., Nelson, W. C., Radune, D., Romero, C. M., Sarria, S., Selengut, J., Shamblin, C., Sullivan, S. A., White, O., Yu, Y., Zafar, N., Zhou, L., and Fraser, C. M. (2004). Structural flexibility in the Burkholderia mallei genome. Proc. Natl. Acad. Sci. U.S.A. 101, 14246-14251.

Peppoloni, S., Ruggiero, P., Contorni, M., Morandi, M., Pizza, M., Rappuoli, R., Podda, A., and Del Giudice, G. (2003). Mutants of the Escherichia coli heat-labile enterotoxin as safe and strong adjuvants for intranasal delivery of vaccines. Expert Rev. Vaccines 2, 285-293.

Relman, D. A. (2011). Microbial genomics and infectious diseases. $N$. Engl. J. Med. 365, 347-357.

Sedegah, M., Charoenvit, Y., Minh, L., Belmonte, M., Majam, V. F., Abot, S., Ganeshan, H., Kumar, S., Bacon, D. J., Stowers, A., Narum, D. L., Carucci, D. J., and Rogers, W. O. (2004). Reduced immunogenicity of DNA vaccine plasmids in mixtures. Gene Ther. 11, 448-456.

Stemke-Hale, K., Kaltenboeck, B., Degraves, F. J., Sykes, K. F., Huang, J., Bu, C. H., Johnston, S. A., StemkeHale, K., Kaltenboeck, B., Degraves, F. J., Sykes, K. F., Huang, J., Bu, C.-H., and Johnston, S. A. (2005). Screening the whole genome of a pathogen in vivo for individual protective antigens. Vaccine 23, 3016-3025.

Svarovsky, S., Borovkov, A., and Sykes, K. (2008). Cationic gold microparticles for biolistic delivery of nucleic acids. Biotechniques 45, 535-540.

Svarovsky, S. A., Gonzalez-Moa, M. J. Robida, M. D., Borovkov, A. Y., and Sykes, K. (2009). Self-assembled micronanoplexes for improved biolistic delivery of nucleic acids. Mol. Pharm. 6, 1927-1933.

Sykes, K. F., and Johnston, S. A. (1999a). Genetic live vaccines mimic the antigenicity but not pathogenicity of live viruses. DNA Cell Biol. 18, 521-531.

Sykes, K. F., and Johnston, S. A. (1999b). Linear expression elements: a rapid, in vivo, method to screen for gene functions. Nat. Biotechnol. 17 355-359.

Tang, D. C., Devit, M., and Johnston, S. A. (1992). Genetic immunization is a simple method for eliciting an immune response. Nature 356 152-154.

Ulrich, R. L., Amemiya, K., Waag, D. M., Roy, C. J., and Deshazer, D. (2005). Aerogenic vaccination with a Burkholderia mallei auxotroph protects against aerosol-initiated glanders in mice. Vaccine 23, 1986-1992.

U'Ren, J. M., Schupp, J. M., Pearson, T., Hornstra, H., Friedman, C. L., Smith, K. L., Daugherty, R. R., Rhoton, S. D., Leadem, B., Georgia, S., Cardon, M., Huynh, L. Y., Deshazer, D., Harvey, S. P., Robison, R., Gal, D., Mayo M. J., Wagner, D., Currie, B. J., Keim, P., U'ren, J. M., Schupp, J. M., Pearson, T., Hornstra, H., Friedman, C. L. C., Smith, K. L., Daugherty, R. R. L., Rhoton, S. D., Leadem, B., Georgia, S., Cardon, M., Huynh, L. Y. Deshazer, D., Harvey, S. P., Robison, R., Gal, D., Mayo, M. J., Wagner, D., Currie, B. J., and Keim, P. (2007). Tandem repeat regions within the Burkholderia pseudomallei genome and their application for high resolution genotyping. BMC Microbiol. 7, 23. doi:10.1186/1471-2180-7-23

Waag, D. M., Deshazer, D., Lindler, L. E., Lebeda, F. J., Korch, G. W., and Meselson, M. (eds). (2005). Glanders, New Insights into an Old Disease. Totowa, NJ: Humana Press.

Waters, V. L., and Crosa, J. H. (1991). Colicin V virulence plasmids. Microbiol. Rev. 55, 437-450.

Whitlock, C., Deeraksa, A., Qazi, O., Judy, B. M., Taylor, K., Propst, K. L. Duffy, A. J., Johnson, K., Kitto, G. B., Brown, K. A., Dow, S. W., Torres, A. G., and Estes, D. M. (2010). Protective response to subunit vaccination against intranasal Burkholderia mallei and B. pseudomallei challenge. Procedia Vaccinol. 2, 71-75.

Whitlock, G. C., Estes, D. M., and Torres, A. G. (2007). Glanders: off to the races with Burkholderia mallei. FEMS Microbiol. Lett. 277, 115-122.

Whitlock, G. C., Lukaszewski, R. A., Judy, B. M., Paessler, S., Torres, A. G., and Estes, D. M. (2008). Host immunity in the protective response to vaccination with heat-killed Burkholderia mallei. BMCImmunol. 9, 55 . doi:10.1186/1471-2172-9-55

Yu, C.-S., Lin, C.-J., and Hwang, J.-K. (2004). Predicting subcellular localization of proteins for Gram-negative bacteria by support vector machines based on n-peptide compositions. Protein Sci. 13, 1402-1406.

Yu, N. Y., Wagner, J. R., Laird, M. R., Melli, G., Rey, S., Lo, R., Dao, P., Sahinalp, S. C., Ester, M., Foster, L. J., and Brinkman, F. S. L. (2010). PSORTb 3.0: improved protein subcellular localization prediction with refined localization subcategories and predictive capabilities for all prokaryotes. Bioinformatics 26, 1608-1615.

Zhong, X., Kolter, R., and Tai, P. C. (1996). Processing of colicin V-1, a secretable marker protein of a bacterial ATP binding cassette export system, requires membrane integrity, energy, and cytosolic factors. J. Biol. Chem. 271, 28057-28063.

Conflict of Interest Statement: The authors declare that the research was conducted in the absence of any commercial or financial relationships that could be construed as a potential conflict of interest.

Received: 20 August 2011; paper pending published: 15 September 2011; accepted: 26 October 2011; published online: 21 November 2011.

Citation: Whitlock GC, Robida MD, Judy BM, Qazi O, Brown KA, Deeraksa A, Taylor K, Massey S, Loskutov A, Borovkov AY, Brown K, Cano JA, Magee $D M$, Torres AG, Estes DM and Sykes KF (2011) Protective antigens against glanders identified by expression library immunization. Front. Microbio. 2:227. doi: 10.3389/fmicb.2011.00227

This article was submitted to Frontiers in Cellular and Infection Microbiology, a specialty of Frontiers in Microbiology. Copyright (c) 2011 Whitlock, Robida, Judy, Qazi, Brown, Deeraksa, Taylor, Massey, Loskutov, Borovkov, Brown, Cano, Magee, Torres, Estes and Sykes. This is an open-access article subject to a non-exclusive license between the authors and Frontiers Media SA, which permits use, distribution and reproduction in other forums, provided the original authors and source are credited and other Frontiers conditions are complied with. 


\section{APPENDIX}

Table A1 | Challenge protection results from ELI screen.

\begin{tabular}{|c|c|c|c|c|c|}
\hline Group & Protection score ( $p$-value) & Rank & Group & Protection score ( $p$-value) & Rank \\
\hline Y2 & $131(0.66)$ & 26 & $x 42$ & $128(0.09)$ & 52 \\
\hline Y4 & $177(0.62)$ & 14 & $\mathrm{X} 44$ & $83(0.02)$ & 56 \\
\hline Y5 & $107(0.35)$ & 37 & X45 & $129(0.10)$ & 51 \\
\hline Y8 & $177(0.62)$ & 12 & X48 & $186(0.45)$ & 39 \\
\hline Y9 & $131(0.66)$ & 26 & X49 & $177(0.37)$ & 45 \\
\hline Y10 & $134(0.70)$ & 24 & $x 50$ & $231(0.96)$ & 23 \\
\hline Y11 & $149(0.93)$ & 19 & $x 51$ & $269(0.59)$ & 21 \\
\hline Y12 & $110(0.38)$ & 36 & $x 52$ & $273(0.54)$ & 13 \\
\hline Y17 & $131(0.66)$ & 26 & $\times 57$ & $372(0.03)$ & 2 \\
\hline Y18 & $92(0.22)$ & 41 & $x 58$ & $270(0.57)$ & 18 \\
\hline Y19 & $270(0.02)$ & 1 & $\times 59$ & $365(0.04)$ & 3 \\
\hline Y20 & $177(0.62)$ & 14 & $x 60$ & $183(0.42)$ & 40 \\
\hline Y21 & $146(0.89)$ & 18 & X61 & $227(0.91)$ & 30 \\
\hline Y22 & $95(0.24)$ & 39 & $x 62$ & $210(0.71)$ & 37 \\
\hline Y23 & $180(0.58)$ & 7 & X63 & $231(0.96)$ & 24 \\
\hline Y24 & $233(0.11)$ & 3 & $X 64$ & $291(0.37)$ & 7 \\
\hline Y25 & $138(0.77)$ & 32 & X65 & $183(0.42)$ & 54 \\
\hline Y26 & $135(0.72)$ & 22 & $x 66$ & $180(0.40)$ & 41 \\
\hline Y27 & $86(0.17)$ & 43 & $x 67$ & $159(0.24)$ & 49 \\
\hline Y35 & $84(0.16)$ & 44 & $\times 75$ & $321(0.17)$ & 4 \\
\hline Y36 & $179(0.60)$ & 9 & $\times 76$ & $317(0.20)$ & 6 \\
\hline Y37 & $131(0.66)$ & 26 & $\times 77$ & $180(0.40)$ & 41 \\
\hline Y38 & $191(0.45)$ & 5 & X78 & $224(0.87)$ & 33 \\
\hline Y39 & $179(0.60)$ & 9 & X79 & $270(0.57)$ & 17 \\
\hline Y40 & $138(0.77)$ & 20 & x80 & $270(0.57)$ & 18 \\
\hline Y41 & $135(0.72)$ & 22 & X81 & $189(0.48)$ & 38 \\
\hline Y42 & $182(0.56)$ & 6 & X82 & $173(0.33)$ & 47 \\
\hline Y43 & $134(0.70)$ & 24 & x83 & $176(0.36)$ & 48 \\
\hline Y44 & $180(0.58)$ & 8 & X84 & $270(0.57)$ & 18 \\
\hline Y45 & $119(0.49)$ & 35 & X85 & $230(0.94)$ & 25 \\
\hline Y46 & $177(0.62)$ & 12 & x86 & $276(0.51)$ & 10 \\
\hline Y47 & $93(0.23)$ & 40 & X87 & $276(0.51)$ & 8 \\
\hline Y48 & $126(0.59)$ & 34 & x88 & $227(0.91)$ & 30 \\
\hline Naïve 1 & $146(0.89)$ & & x89 & $423(0.003)$ & 1 \\
\hline Irrelevant & $126(0.59)$ & & x90 & $224(0.87)$ & 33 \\
\hline Vaccine 1 & $336(0.0003)$ & & X91 & $227(0.91)$ & 30 \\
\hline Vaccine 2 & $456(<0.0001)$ & & x92 & $276(0.51)$ & 8 \\
\hline
\end{tabular}




\begin{tabular}{llr}
\hline X93 & $276(0.51)$ & 10 \\
X94 & $228(0.92)$ & 29 \\
X95 & $318(0.19)$ & 5 \\
X96 & $230(0.94)$ & 26 \\
Naïve 1 & $224(0.87)$ & \\
Naïve 2 & $183(0.42)$ & \\
Irrelevant & $192(0.51)$ & \\
Vaccine & $456(0.0005)$ & \\
\hline
\end{tabular}

\begin{tabular}{|c|c|c|}
\hline Group & Average spleen weight (g) & Rank \\
\hline $\mathrm{X} 1$ & 1.43 & 28 \\
\hline$\times 2$ & 1.25 & 18 \\
\hline $\mathrm{X} 3$ & 1.67 & 38 \\
\hline X4 & 1.53 & 33 \\
\hline X5 & 1.04 & 8 \\
\hline $\mathrm{X} 6$ & 1.13 & 11 \\
\hline$\times 7$ & 1.19 & 15 \\
\hline X8 & 1.46 & 29 \\
\hline X9 & 1.13 & 11 \\
\hline $\mathrm{X} 10$ & 1.02 & 6 \\
\hline $\mathrm{X} 11$ & 1.51 & 32 \\
\hline $\mathrm{X} 12$ & 1.29 & 20 \\
\hline $\mathrm{X} 13$ & 1.32 & 22 \\
\hline $\mathrm{X} 14$ & 1.61 & 34 \\
\hline X15 & 1.30 & 21 \\
\hline $\mathrm{X} 16$ & 1.62 & 35 \\
\hline $\mathrm{X} 17$ & 1.62 & 35 \\
\hline X18 & 1.50 & 31 \\
\hline X19 & 1.62 & 35 \\
\hline $\mathrm{X} 20$ & 1.35 & 25 \\
\hline X21 & 1.49 & 30 \\
\hline X22 & 1.71 & 39 \\
\hline $\mathrm{X} 23$ & 1.20 & 17 \\
\hline$\times 24$ & 1.90 & 40 \\
\hline$\times 25$ & 1.07 & 9 \\
\hline X26 & 1.18 & 14 \\
\hline$\times 27$ & 1.19 & 15 \\
\hline X28 & 1.33 & 24 \\
\hline$\times 29$ & 1.02 & 7 \\
\hline X30 & 1.01 & 5 \\
\hline X31 & 1.32 & 22 \\
\hline X32 & 0.91 & 1 \\
\hline X33 & 1.27 & 19 \\
\hline X34 & 1.15 & 13 \\
\hline X35 & 0.97 & 4 \\
\hline X36 & 0.95 & 3 \\
\hline X37 & 0.91 & 1 \\
\hline X38 & 1.36 & 26 \\
\hline X39 & 1.11 & 10 \\
\hline$X 40$ & 1.36 & 26 \\
\hline Naïve uninfected & 1.00 & \\
\hline Naïve infected & 1.25 & \\
\hline
\end{tabular}

